\title{
Eionea nigra gen. nov., sp. nov., a gammaproteobacterium from the Mediterranean Sea
}

Correspondence

Philippe Lebaron

lebaron@obs-banyuls.fr

\author{
Laurent Urios, $^{1,2}$ Laurent Intertaglia, ${ }^{1,2}$ Françoise Lesongeur ${ }^{3}$ \\ and Philippe Lebaron ${ }^{1,2}$
}

\author{
${ }^{1}$ Université Pierre et Marie Curie-Paris 6, Laboratoire ARAGO, Avenue Fontaulé, F-66650 \\ Banyuls-sur-Mer, France \\ ${ }^{2}$ CNRS, UMR 7621, Laboratoire d'Océanographie Microbienne, Avenue Fontaulé, F-66650 \\ Banyuls-sur-Mer, France \\ ${ }^{3}$ Laboratoire de Microbiologie des Environnements Extrêmes, UMR 6197, IFREMER, Centre de \\ Brest, BP70, F-29280 Plouzané, France
}

A novel aerobic, Gram-negative bacterial strain, designated $17 \mathrm{X} / \mathrm{A02} 2 \mathrm{237^{ \top }}$, was isolated from waters of the coastal north-western Mediterranean Sea. Cells were motile straight rods and formed dark-grey colonies on marine agar medium. Strain $17 \mathrm{X} / \mathrm{A02} / 237^{\top}$ contained ubiquinone Q-8 and its major fatty acids were $\mathrm{C}_{16: 1} \omega 7 c$ and/or iso- $\mathrm{C}_{15: 0} 2-\mathrm{OH}, \mathrm{C}_{18: 1} \omega 7 c, \mathrm{C}_{16: 0}, \mathrm{C}_{18: 0}$ and $\mathrm{C}_{10: 0} 3-\mathrm{OH}$. The $\mathrm{G}+\mathrm{C}$ content of the genomic DNA was $47.5 \mathrm{~mol} \%$. Phylogenetic analysis of the 16S rRNA gene sequence placed the strain in the class Gammaproteobacteria. Based on 16S rRNA gene sequence data, as well as physiological and biochemical characteristics, this isolate represents a novel species of a new genus, for which the name of Eionea nigra gen. nov., sp. nov. is proposed. The type strain is $17 \mathrm{X} / \mathrm{A02} / 237^{\top}\left(=\mathrm{DSM} 19752^{\top}=\mathrm{CIP} 109759^{\top}=\mathrm{MOLA}\right.$ $\left.288^{\top}\right)$.
Bugula simplex and Bugula neritina are marine bryozoans that produce bryostatins (Lim \& Haygood, 2004; Haygood \& Davidson, 1997). These compounds confer a chemical defence to the larvae but are also of biotechnological interest, having potential as anticancer drugs (Hale et al., 2002; Winegarden et al., 2003). These bryozoans harbour bacterial symbionts that may play a role in the production of bryostatins (Lim \& Haygood, 2004). Although these symbionts have not been cultured or fully characterized, molecular analysis has led to the identification of two Candidatus species, 'Candidatus Endobugula sertula' and 'Candidatus Endobugula glebosa' (Haygood \& Davidson, 1997; Lim \& Haygood, 2004), which are affiliated to the class Gammaproteobacteria. Their closest described relative is the type strain of Teredinibacter turnerae (Distel et al., 2002) with a $16 \mathrm{~S}$ rRNA gene sequence similarity value of $92 \%$.

In this study, a strain, designated $17 \mathrm{X} / \mathrm{A} 02 / 237^{\mathrm{T}}$, was isolated from seawater. On the basis of $16 \mathrm{~S}$ rRNA gene sequence similarities, the closest relative was 'Candidatus Endobugula glebosa' (94\% similarity) and the closest relative with a validly published name was the type strain of T. turnerae (92\% similarity). Thus, the taxonomic position

The GenBank/EMBL/DDBJ accession number for the 16S rRNA gene sequence of strain $17 \mathrm{X} / \mathrm{A02} / 237^{\top}$ is AY576771. and characteristics of the novel isolate were analysed. On the basis of the results, the name Eionea nigra gen. nov., sp. nov. is proposed to accommodate strain $17 \mathrm{X} / \mathrm{A} 02 / 237^{\mathrm{T}}$.

Samples were collected in October 2002 in the bay of Banyuls-sur-Mer $\left(42^{\circ} 29^{\prime} \mathrm{N} 3^{\circ} 08^{\prime} \mathrm{E}\right)$. Subsamples were spread on marine agar plates (MA 2216; Difco) and incubated at $25{ }^{\circ} \mathrm{C}$ for 2 weeks. Colonies were picked and purified after three stages of subculturing. Among these colonies, an isolate forming dark-grey-coloured colonies was obtained and referenced as strain $17 \mathrm{X} / \mathrm{A} 02 / 237^{\mathrm{T}}$ (Agogué et al., 2005).

Microscopic observations (Olympus AX70) showed that cells of strain $17 \mathrm{X} / \mathrm{A} 02 / 237^{\mathrm{T}}$ were motile rods. Negatively stained cells (Raguénès et al., 1997) were $\sim 1.4 \pm 0.1 \times$ $0.5 \pm 0.05 \mu \mathrm{m}$ in size and a polar flagellum was observed. The Ryu $\mathrm{KOH}$ reaction (Powers, 1995) led to immediate cell lysis, which was confirmed by microscopy (Olympus AX70). This positive reaction indicated that the strain was Gram-negative.

The isolate was routinely grown in marine broth medium (MB 2216; Difco). To determine the salinity tolerance range of $17 \mathrm{X} / \mathrm{A} 02 / 237^{\mathrm{T}}, \mathrm{MB} 2216$, prepared according to the manufacturer's instructions, containing various $\mathrm{NaCl}$ concentrations was used. Growth was determined at 
Table 1. Differential characteristics of strain $17 \mathrm{X} / \mathrm{A} 02 / 237^{\top}$ and related species

Strains: 1, 17X/A02/237 ${ }^{\mathrm{T}}$; 2, Teredinibacter turnerae DSM $15152^{\mathrm{T}}$ (Distel et al., 2002); 3, Saccharophagus degradans DSM 17024 ${ }^{\mathrm{T}}$ (Ekborg et al., 2005; González \& Weiner, 2000); 4, Dasania marina JCM 13441 ${ }^{\mathrm{T}}$ (Lee et al., 2007); 5, Haliea salexigens DSM 19537 ${ }^{\mathrm{T}}$ (Urios et al., 2008b); 6, Melitea salexigens DSM $19753^{\mathrm{T}}$ (Urios et al., 2008a). +, Positive; -, negative; (+), weakly positive; ND, not determined. API ZYM data for T. turnerae and S. degradans are from this study.

\begin{tabular}{|c|c|c|c|c|c|c|}
\hline Characteristic & 1 & 2 & 3 & 4 & 5 & 6 \\
\hline Sampling environment & Seawater & $\begin{array}{l}\text { Lyrodus } \\
\text { pedicellatus }\end{array}$ & $\begin{array}{l}\text { Spartina } \\
\text { alterniflora }\end{array}$ & $\begin{array}{l}\text { Marine } \\
\text { sediment }\end{array}$ & Seawater & Seawater \\
\hline DNA G $+C$ content $(\mathrm{mol} \%)$ & 47.5 & $49-51$ & 45.8 & 37 & 61.4 & 57.2 \\
\hline \multicolumn{7}{|l|}{ Growth temperature $\left({ }^{\circ} \mathrm{C}\right)$} \\
\hline Range & $10-44$ & $15-40$ & $4-37$ & $4-30$ & $10-37$ & $15-37$ \\
\hline Optimum & 30 & 30 & 30 & $17-22$ & 25 & 30 \\
\hline \multicolumn{7}{|l|}{ Growth salinity $\left(\mathrm{g} \mathrm{l}^{-1}\right)$ : } \\
\hline Range & $7-70$ & $6-36$ & $7-70$ & $10-90$ & $7-70$ & $7-70$ \\
\hline Optimum & 35 & 18 & 25 & 35 & 42 & 28 \\
\hline \multicolumn{7}{|l|}{ Growth pH: } \\
\hline Range & $5.0-9.0$ & $6.0-10.5$ & $4.5-10.0$ & $7-10$ & $5-9$ & $6-10$ \\
\hline Optimum & 8.0 & 8.5 & 7.5 & $7-8$ & 8 & 8 \\
\hline Major quinone & Q-8 & ND & ND & Q-8 & Q-8 & Q-8 \\
\hline \multicolumn{7}{|l|}{ API ZYM tests: } \\
\hline Alkaline phosphatase & + & + & + & + & + & + \\
\hline Valine arylamidase & - & $(+)$ & $(+)$ & ND & + & - \\
\hline$N$-Acetyl- $\beta$-glucosaminidase & - & - & - & - & - & $(+)$ \\
\hline Esterase (C4) & $(+)$ & - & - & - & - & - \\
\hline Lipase (C8) & - & + & - & - & $(+)$ & $(+)$ \\
\hline Naphthol-AS-B1-phosphohydrolase & $(+)$ & + & $(+)$ & ND & + & + \\
\hline \multicolumn{7}{|l|}{ Utilization of: } \\
\hline Cellobiose & - & + & $\mathrm{ND}$ & - & - & $(+)$ \\
\hline Fructose & $(+)$ & + & + & - & - & + \\
\hline Galactose & - & ND & + & - & - & - \\
\hline Glucose & + & + & + & - & - & + \\
\hline Lactose & - & ND & + & - & - & $(+)$ \\
\hline Maltose & - & ND & + & - & - & + \\
\hline Mannose & - & ND & + & - & $(+)$ & + \\
\hline Raffinose & - & ND & ND & - & - & + \\
\hline Sucrose & - & + & + & - & - & + \\
\hline Glycerol & - & ND & ND & - & + & - \\
\hline Mannitol & + & ND & $\mathrm{ND}$ & - & - & - \\
\hline Acetate & - & + & ND & $\mathrm{ND}$ & - & $(+)$ \\
\hline Aspartate & - & ND & ND & ND & + & - \\
\hline Glutamate & - & + & $\mathrm{ND}$ & $\mathrm{ND}$ & $(+)$ & $(+)$ \\
\hline$\beta$-Hydroxybutyrate & - & ND & ND & $\mathrm{ND}$ & + & - \\
\hline Pyruvate & - & + & $\mathrm{ND}$ & $\mathrm{ND}$ & + & - \\
\hline Citrate & + & ND & ND & $\mathrm{ND}$ & - & - \\
\hline Succinate & - & + & $\mathrm{ND}$ & $\mathrm{ND}$ & + & - \\
\hline Alanine & - & $\mathrm{ND}$ & $\mathrm{ND}$ & $\mathrm{ND}$ & - & $(+)$ \\
\hline Leucine & - & $\mathrm{ND}$ & $\mathrm{ND}$ & $\mathrm{ND}$ & + & - \\
\hline Proline & + & ND & ND & ND & + & - \\
\hline Tween 80 & - & ND & + & ND & + & - \\
\hline
\end{tabular}

different $\mathrm{pH}$ levels by adjusting $\mathrm{MB}$ with MES, PIPES, AMPSO or MOPS buffers (Sigma). Cultures were incubated at $30{ }^{\circ} \mathrm{C}$ under aerobic conditions. Methods for the determination of growth parameters were used as described by Wery et al. (2001b). Growth was observed at $10-44{ }^{\circ} \mathrm{C}$, with optimum growth at $30{ }^{\circ} \mathrm{C}$; growth rate values were $9 \%$ lower at $25{ }^{\circ} \mathrm{C}$ and $25 \%$ lower at $37{ }^{\circ} \mathrm{C}$. The strain grew at
$\mathrm{NaCl}$ concentrations ranging from 7 to $70 \mathrm{~g} \mathrm{l}^{-1}$, with optimum growth at $35 \mathrm{~g} \mathrm{l}^{-1}$; growth decreased by $40 \%$ at $42 \mathrm{~g} \mathrm{l}^{-1}$ and $8 \%$ at $28 \mathrm{~g} \mathrm{l}^{-1}$. Growth occurred at $\mathrm{pH} 5-9$, with optimum growth at $\mathrm{pH} 8$; growth decreased by $90 \%$ at $\mathrm{pH} 9$ compared with growth at $\mathrm{pH} 8$ and a growth variation of only $15 \%$ occurred between $\mathrm{pH} 8$ and $\mathrm{pH} 6$. To investigate the possibility of growth under anaerobic 
Table 2. Cellular fatty acid composition (\%) of strain $17 \mathrm{X} / \mathrm{A} 02 / 237^{\top}$ and related species

Strains: 1, 17X/A02/237 ${ }^{\mathrm{T}}$; 2, Saccharophagus degradans DSM $17024^{\mathrm{T}}$ (González \& Weiner, 2000); 3, Dasania marina JCM 13441 ${ }^{\mathrm{T}}$ (Lee et al., 2007); 4, Haliea salexigens DSM $19537^{\mathrm{T}}$ (Urios et al., 2008b); 5, Melitea salexigens DSM 19753 ${ }^{\mathrm{T}}$ (Urios et al., 2008a). tr, Trace; -, not detected.

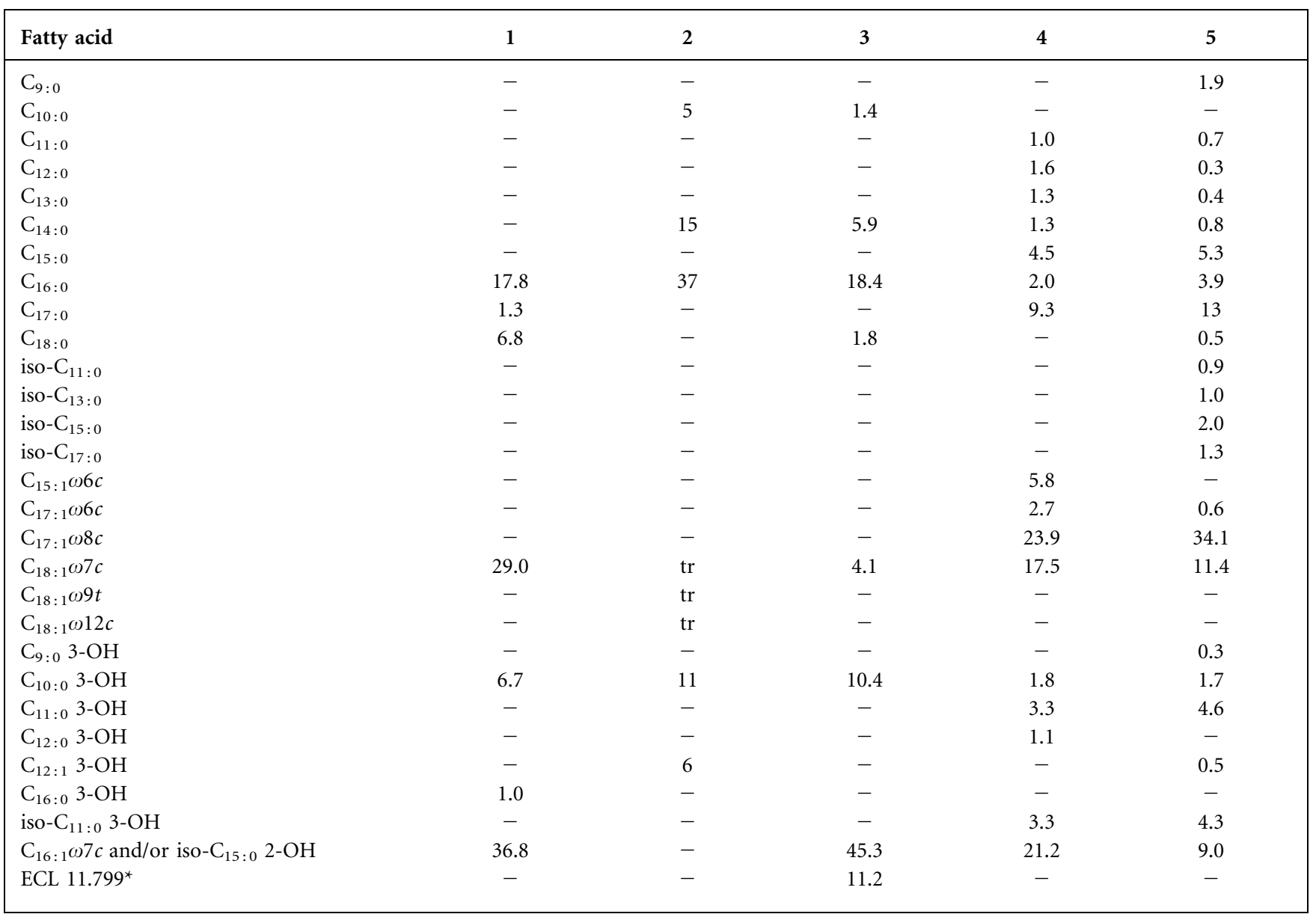

${ }^{\star}$ ECL, Equivalent chain-length.

conditions, cultures were grown in anaerobic jars on MA 2216 plates under optimal temperature, $\mathrm{pH}$ and salinity conditions. No growth was observed after 10 days and, thus, the strain was considered to be strictly aerobic.

The ability of strain $17 \mathrm{X} / \mathrm{A} 02 / 237^{\mathrm{T}}$ to utilize different substrates was investigated using Biolog GN2 MicroPlates (Tang et al., 1998) according to the manufacturer's instructions. Positive reactions were obtained with $\mathrm{D}$ glucose, D-mannitol, citrate and L-proline. Weakly positive reactions were observed for erythritol and D-fructose. A comparison of substrate utilization by strain $17 \mathrm{X} / \mathrm{A} 02 / 237^{\mathrm{T}}$ and its closest relatives is presented in Table 1.

Enzymic activities were investigated using the API ZYM system (bioMérieux) according to the manufacturer's instructions. Strain $17 \mathrm{X} / \mathrm{A} 02 / 237^{\mathrm{T}}$ was positive for alkaline phosphatase activity, whereas esterase (C4) and naphtholAS-B1-phosphohydrolase activities were weakly positive (Table 1).
Fatty acid methyl ester analysis was performed by the DSMZ Identification Service (Braunschweig, Germany). Biomass was harvested from colonies cultivated on MA plates under optimal conditions. The fatty acid composition of strain $17 \mathrm{X} / \mathrm{A} 02 / 237^{\mathrm{T}}$ was (\%): $\mathrm{C}_{16: 1} \omega 7 c$ and/or iso- $\mathrm{C}_{15: 0} 2-\mathrm{OH}$ (36.8), $\mathrm{C}_{18: 1} \omega 7 c$ (29.0), $\mathrm{C}_{16: 0}$ (17.8), $\mathrm{C}_{18: 0}$ (6.8), $\mathrm{C}_{10: 0} 3-$ $\mathrm{OH}$ (6.7), $\mathrm{C}_{17: 0}(1.3)$ and $\mathrm{C}_{16: 0} 3-\mathrm{OH}$ (1.0). Of all the strains studied (Table 2), $\mathrm{C}_{16: 0} 3-\mathrm{OH}$ was only detected in strain $17 \mathrm{X} / \mathrm{A} 02 / 237^{\mathrm{T}}, \mathrm{C}_{14: 0}$ was found in all strains except for strain $17 \mathrm{X} / \mathrm{A} 02 / 237^{\mathrm{T}}$ and $\mathrm{C}_{18: 0}$ and $\mathrm{C}_{18: 1} \omega 7 c$ were present in significantly higher amounts in strain 17X/A02/ $237^{\mathrm{T}}$ than in the other strains.

Analysis of respiratory quinones and polar lipids was carried out by the DSMZ Identification Service (Braunschweig, Germany). Strain $17 \mathrm{X} / \mathrm{A} 02 / 237^{\mathrm{T}}$ contained ubiquinone-8 (97\%) and ubiquinone-7 (3\%).

Genomic DNA was extracted as described by Wery et al. (2001a). The DNA G+C content was determined by 


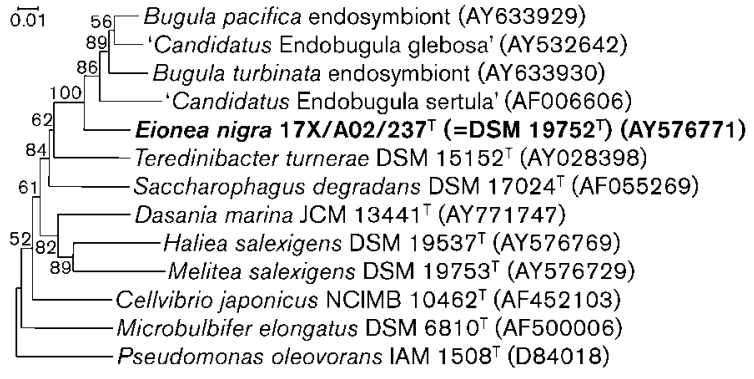

Fig. 1. Phylogenetic tree showing the position of strain 17X/A02/ $237^{\top}$. Accession numbers and type strains are indicated. The tree corresponds to an unrooted tree obtained by the neighbour-joining algorithm (Kimura corrections). Bootstrap values $>50 \%$ (based on 1000 resamplings) are shown at nodes. Bar, 0.01 substitutions per nucleotide position.

thermal denaturation using the method of Marmur \& Doty (1962) under conditions described by Raguénès et al. (1997). The G $+C$ content of the genomic DNA of strain $17 \mathrm{X} / \mathrm{A} 02 / 237^{\mathrm{T}}$ was $47.5 \pm 0.5 \mathrm{~mol} \%$. The $16 \mathrm{~S} \mathrm{rRNA}$ gene was amplified and sequenced as described by Agogué et al. (2005). The sequence was analysed as described by Urios et al. (2006). Strain $17 \mathrm{X} / \mathrm{A} 02 / 237^{\mathrm{T}}$ was phylogenetically affiliated to the class Gammaproteobacteria (Fig. 1). Its closest relatives were T. turnerae DSM $15152^{\mathrm{T}}$ and Saccharophagus degradans DSM $17024^{\mathrm{T}}$, with similarity values of 92 and $91 \%$, respectively.

Strain $17 \mathrm{X} / \mathrm{A} 02 / 237^{\mathrm{T}}$ could be distinguished from its nearest phylogenetic relatives by differences in their phenotypic properties (Table 1), fatty acid composition (Table 2) and 16S rRNA gene sequences. Based on these differences, strain $17 \mathrm{X} / \mathrm{A} 02 / 237^{\mathrm{T}}$ represents a novel species in a new genus, for which the name Eionea nigra gen. nov., sp. nov. is proposed.

\section{Description of Eionea gen. nov.}

Eionea (Ei.on'e.a. N.L. fem. n. Eionea a nymph of the sea, referring to the marine origin of the type strain).

Cells are motile Gram-negative rods. The two dominant fatty acids are $\mathrm{C}_{16: 1} \omega 7 c$ and/or iso- $\mathrm{C}_{15: 0} 2-\mathrm{OH}$ and $\mathrm{C}_{18: 1} \omega 7 c$. The major ubiquinone is ubiquinone Q-8. Phylogenetically affiliated to the class Gammaproteobacteria. The type species is Eionea nigra.

\section{Description of Eionea nigra sp. nov.}

Eionea nigra (ni'gra. L. adj. nigra black, referring to the colour of the colonies of the type strain).

Forms dark-grey colonies on MA medium. Cells are motile Gram-negative rods, $1.4 \pm 0.1 \times 0.5 \pm 0.5 \mu \mathrm{m}$, with a single polar flagellum. Growth occurs at $10-44{ }^{\circ} \mathrm{C}$ (optimum $30{ }^{\circ} \mathrm{C}$ ), at $\mathrm{pH} 5-9$ (optimum $\mathrm{pH}$ 8) and in 7-70 $\mathrm{g} \mathrm{NaCl}$ $\mathrm{l}^{-1}$ (optimum $35 \mathrm{~g} \mathrm{l}^{-1}$ ). Positive reactions with Biolog
GN2 plates were obtained for D-glucose, D-mannitol, citrate and L-proline. In API ZYM tests, alkaline phosphatase acitivity is positive and esterase (C4) and naphtholAS-B1-phosphohydrolase activities are weakly positive. Oxidase-negative and catalase-positive. The major fatty acids are $\mathrm{C}_{16: 1} \omega 7 c$ and/or iso- $\mathrm{C}_{15: 0}$ 2- $\mathrm{OH}, \mathrm{C}_{18: 1} \omega 7 c$, $\mathrm{C}_{16: 0}, \mathrm{C}_{18: 0}$ and $\mathrm{C}_{10: 0} 3-\mathrm{OH}$.

The type strain, $17 \mathrm{X} / \mathrm{A} 02 / 237^{\mathrm{T}}\left(=\mathrm{DSM} 19752^{\mathrm{T}}=\mathrm{CIP} 109759^{\mathrm{T}}\right.$ $=$ MOLA $288^{\mathrm{T}}$ ), was isolated from a water column in the bay of Banyuls-sur-Mer $\left(42^{\circ} 29^{\prime} \mathrm{N} 3^{\circ} 08^{\prime} \mathrm{E}\right)$. The DNA G + C content of strain $17 \mathrm{X} / \mathrm{A} 02 / 237^{\mathrm{T}}$ is $47.5 \mathrm{~mol} \%$.

\section{Acknowledgements}

This work was supported by the Equipe Mixte de Recherche linking the Université Pierre et Marie Curie and the Centre National de la Recherche Scientifique to the Pierre Fabre Laboratories.

\section{References}

Agogué, H., Casamayor, E. O., Bourrain, M., Obernosterer, I., Joux, F., Herndl, G. J. \& Lebaron, P. (2005). A survey on bacteria inhabiting the sea surface microlayer of coastal ecosystems. FEMS Microbiol Ecol 54, 269-280.

Distel, D. L., Morrill, W., MacLaren-Toussaint, N., Franks, D. \& Waterbury, J. (2002). Teredinibacter turnerae gen. nov., sp. nov., a dinitrogen-fixing, cellulolytic, endosymbiotic $\gamma$-proteobacterium isolated from the gills of wood-boring molluscs (Bivalvia: Teredinidae). Int J Syst Evol Microbiol 52, 2261-2269.

Ekborg, N. A., Gonzalez, J. M., Howard, M. B., Taylor, L. E., Hutcheson, S. W. \& Weiner, R. M. (2005). Saccharophagus degradans gen. nov., sp. nov., a versatile marine degrader of complex polysaccharides. Int $J$ Syst Evol Microbiol 55, 1545-1549.

González, J. M. \& Weiner, R. M. (2000). Phylogenetic characterization of marine bacterium strain 2-40, a degrader of complex polysaccharides. Int J Syst Evol Microbiol 50, 831-834.

Hale, K. J., Hummersone, M. G., Manaviazar, S. \& Frigerio, M. (2002). The chemistry and biology of the bryostatin antitumour macrolides. Nat Prod Rep 19, 413-453.

Haygood, M. G. \& Davidson, S. K. (1997). Small-subunit rRNA genes and in situ hybridization with oligonucleotides specific for the bacterial symbionts in the larvae of the bryozoan Bugula neritina and proposal of "Candidatus Endobugula sertula". Appl Environ Microbiol 63, 4612-4616.

Lee, Y. K., Hong, S. G., Cho, H. H., Cho, K. H. \& Lee, H. K. (2007). Dasania marina gen. nov., sp. nov., of the order Pseudomonadales, isolated from Arctic marine sediment. J Microbiol 45, 505-509.

Lim, G. E. \& Haygood, M. G. (2004). "Candidatus Endobugula glebosa", a specific bacterial symbiont of the marine bryozoan Bugula simplex. Appl Environ Microbiol 70, 4921-4929.

Marmur, J. \& Doty, P. (1962). Determination of the base composition of deoxyribonucleic acid from its thermal denaturation temperature. J Mol Biol 5, 109-118.

Powers, E. M. (1995). Efficacy of the Ryu nonstaining KOH technique for rapidly determining Gram reactions of food-borne and waterborne bacteria and yeasts. Appl Environ Microbiol 61, 3756-3758.

Raguénès, G., Christen, R., Guézennec, J., Pignet, P. \& Barbier, G. (1997). Vibrio diabolicus sp. nov., a new polysaccharide-secreting organism isolated from a deep-sea hydrothermal vent polychaete annelid, Alvinella pompejana. Int J Syst Bacteriol 47, 989-995. 
Tang, Y. W., Ellis, N. M., Hopkins, M. K., Smith, D. H., Dodge, D. E. \& Persing, D. H. (1998). Comparison of phenotypic and genotypic techniques for identification of unusual aerobic pathogenic Gramnegative bacilli. J Clin Microbiol 36, 3674-3679.

Urios, L., Agogué, H., Lesongeur, F., Stackebrandt, E. \& Lebaron, P. (2006). Balneola vulgaris gen. nov., sp. nov., a member of the phylum Bacteroidetes from the north-western Mediterranean Sea. Int J Syst Evol Microbiol 56, 1883-1887.

Urios, L., Agogué, H., Intertaglia, L., Lesongeur, F. \& Lebaron, P. (2008a). Melitea salexigens gen. nov., sp. nov., a gammaproteobacterium from the Mediterranean Sea. Int J Syst Evol Microbiol 58, 2479-2483.

Urios, L., Intertaglia, L., Lesongeur, F. \& Lebaron, P. (2008b). Haliea salexigens gen. nov., sp. nov., a member of the Gammaproteobacteria from the Mediterranean Sea. Int J Syst Evol Microbiol 58, 1233-1237.
Wery, N., Lesongeur, F., Pignet, P., Derennes, V., Cambon-Bonavita, M. A., Godfroy, A. \& Barbier, G. (2001a). Marinitoga camini gen. nov., sp. nov., a rod-shaped bacterium belonging to the order Thermotogales, isolated from a deep-sea hydrothermal vent. Int $J$ Syst Evol Microbiol 51, 495-504.

Wery, N., Moricet, J. M., Cueff, V., Jean, J., Pignet, P., Lesongeur, F., Cambon-Bonavita, M. A. \& Barbier, G. (2001b). Caloranaerobacter azorensis gen. nov., sp. nov., an anaerobic thermophilic bacterium isolated from a deep-sea hydrothermal vent. Int J Syst Evol Microbiol 51, 1789-1796.

Winegarden, J. D., Mauer, A. M., Gajewski, T. F., Hoffman, P. C., Krauss, S., Rudin, C. M. \& Vokes, E. E. (2003). A phase II study of bryostatin-1 and paclitaxel in patients with advanced non-small cell lung cancer. Lung Cancer 39, 191-196. 